\title{
THE SPATIAL EXTENSION AND THE AGE OF THE TOMNATEC FORMATION IN AUDIA NAPPE
}

\author{
LIVIU IONESI, FLORIN FLOREA
}

KEYWORDS: Thanetian - Priabonian, calcareous nannoplankton, Tomnatec Formation, Audia Nappe, East Carpathian Flysch

In the northern area of Audia Nappe, in between Sălătruc River (a right hand tributary of Moldova River) and the northern border of our country, the Tomnatec Formation crops out. It unconformably overlies the Variegated Formation (Vraconian Maastrichtian) and is covered by lonul Formation (Priabonian). We have to mention that the Tomnatec Formation is better developed in the eastern part of Audia Nappe whereas on the rest of it crops out only sporadically. On this basis Ionesi divided Audia Nappe (1965, p. 66-67) in two digitations: the lower one, Prisaca Digitation, in the eastern part and the upper one, Black Shales' Digitation, in the western part. The Black Shales' Digitation is overthrusting upon the Prisaca Digitation after the Feredeu Fault. The lower digitation is tectonically subsided which could explain the better preservation of it while the upper digitation is tectonically uplifted. The upper digitation position is supposed to be the explanation for the missing of Tomnatec Formation from it. The same interpretation was reconsidered and developed by lonesi (1971, p 157-158).

The two digitation defined by lonesi (1965) are represented also on Geological Map of Romania (Câmpulung Map, 1:50 000; Săndulescu et al., 1987) edited by Geological and Geophysical Institute of Romania. Săndulescu (1984, p. 264-265), in Geotectonica României (Geotectonics of Romania) paper, names the Black Shales' Digitation as Inner Digitation. He also considers it as being an equivalent of Cernahora Unit (s. s.) is extended to south along the Audia Nappe. This means that the sandstone which cover the Variegated Formation could be equivalent to Siriu Sandstone (Senonian - Paleocene) and not to Prisaca Sandstone (= Tomnatec Sandstone) of the same digitation.

This point of view is again defended by Săndulescu et al. $(1990,1993)$. In the latter paper the authors exclusively study the sandstone of the inner digitation, which is named Benia Digitation. This sandstone is given the same name as the digitation (Benia Sandstone). The authors think that this sandstone is Santonian Lower Campanian (?) while the sandstone of Prisaca Digitation is considered to be Maastrichtian - Lutetian age. our paper.

We consider the above introduction as being useful in the development of

We propose the name Feredeu Digitation for former named Black Shales' 
Digitation (Ionesi, 1965, 1971) or Inner Digitation (Săndulescu, 1984) or Benia Digitation (Săndulescu et al., 1990, 1993) having in view the name of the front fault, Feredeu Fault (Ionesi, 1965, 1971).

The sandstones which unconformably cover Variegated Formation were distinguished by Paul (1876) and incorporated in the "Middle Carpathian Sandstone" (Cretaceous age). Athanasiu (1913) names them Tomnatec Sandstone and places them in Cenomanian - Senonian span. Later on, Macovei (1927) matches them with Tarcău Sandstone (Eocene age). Băncilă $(1955,1958)$ concludes that these sandstones are older, Senonian - ?Eocene, and names them Prisaca Sandstone. On the basis of priority principle the name Tomnatec Sandstone (Athanasiu, 1913) has to prevail. The combined terms, Tomnatec - Prisaca or Prisaca - Tomnatec (used by us), are not admitted by Hedberg Code. Most part of petrographic and biostratigraphic data, except the ones provided by Săndulescu et al. (1993), are referred to as sandstones of Prisaca Digitation.

Petrographically, Tomnatec Formation is formed by quartzose - feldsparic, feldsparic, lithic and litho - feldsparic sandstones (lonesi et al., 1998; Turturean 1999). All the sandstone varieties mentioned above also contain micas flakes, especially muscovite. The sandstones are interbedded with siltstones and greenish - grey, rarely red, claystones. On Gavriloi River, south of Moldova Valley, crops out a conglomeratic unit $(<12 \mathrm{~m})$ with clasts from Audia Formation (opalithe, quartzose sandstones) and of crystalline schists. The conglomeratic unit has lens shape so that it cannot be used as a marker level. On the basis of sandstone varieties, Turturean (1999) divides the Tomnatec Formation in 4 members:

1. the member of quartzose - feldsparic sandstones;

2. the member of lithic and litho - feldsparic sandstones;

3. the member of claystones and microconglomerates;

4. the member of feldsparic and lithic sandstones.

Despite their mineralogical composition the field appearance is uniform.

Ionesi (in lonesi et al., 1998) signalled a unit of paraconglomerates, ruditic sandstones with clasts from Audia and Variegated formations $(<30 \mathrm{~m})$, rhythmic alternation of thin quartzose sandstones and green claystones $(5 \mathrm{~m})$ and a microconglomeratic bed $(0,8 \mathrm{~m})$ with feldsparic and quartzose clasts. The later one crops out on Demăcuşa River and can be followed up to Roşoşa River. To the southern area of Boului Valley it is hidden under Feredeu Fault plane, in front of Feredeu Digitation.

The age of Tomnatec Formation was and still is a controversial problem. At the beginning it was dated on geometrical position and lithological aspect. On this basis Paul (1860) and Athanasiu (1913) consider it as Cretaceous age because it reposed on the same age deposits while Macovei (1927) dates it as Eocene age because of its resemblance with Tarcau Sandstone. Even if after 1950s paleontological proves (from agglutinate microforaminifera, macroforaminifera, palinomorphes, calcareous nannoplankton) were provided the age of this formation is still a matter of controversy.

Consequently, the Tomnatec Formation was dated back in Upper Turonian Eocene (Băncilă, Agheorghiesei, 1964; Agheorghiesei et al., 1965); the sandstones from Prisaca Digitation were dated as Maastrichtian - Lutetian (Săndulescu et al., 1990); the sandstones from Benia Digitation were considered Santonian - ?Lower 
Campanian (Săndulescu et al., 1993). The entire formation was placed in Paleocene? - Eocene span (Ionesi, 1963, 1965, 1971, 1974; Ionesi et al., 1967), in Paleocene Lutetian span (Ion, 1957) and Upper Thanetian? - Priabonian (Ionesi et al., 1998; Turturean, 1999).

Up to 1990 the massive sandstones in Audia Nappe were considered globally and of the same age, but afterwhile the matter became more complicated. On some agglutinante foraminifera (Dendrophyra robusta, Dendrophyra excelsa, Carpatiella ovulum ovulum, Carpatiella ovulum giganthea etc) and palinomorphes assemblages Săndulescu et al $(1990,1993)$ differently date the sandstones according to their positions in digitations: those from Prisaca in Maastrichtian Lutetian span and those from Benia Digitation in Santonian -?Lower Campanian. The different ages attributed to the sandstones determined us to take also into consideration the calcareous nannoplankton content of which biostratigraphic value is well known.

Ionesi et al. (1998) and Turturean (2000) analysing the calcareous nannoplankton prove that the lowermost part of Tomnatec Formation, in Prisaca Digitation, belongs to $\mathrm{NP}_{9}$ biozone (Cruciplacolithus tenuis, Discoaster multiradiatus, Fasciculithus tympaniformis etc), corresponding to Uppermost Thanetian or Lowermost Ypresian. The upper part of Tomnatec Formation belongs to $\mathrm{NP}_{20}$ (Sphenolithus pseudoradians, Lanternitus minutus, Istmolithus recurvus, Discoaster barbadiensis etc) which means Priabonian age. The Variegated Formation, covered by Tomnatec Sandstone, is attributed to Vraconian $\left(\mathrm{CC}_{9}\right)$ - Upper Maastrichtian $\left(\mathrm{CC}_{26}\right)$ on the basis of calcareous nannoplankton. This fact means that between the Variegated Formation and Tomnatec Formation there is a stratigraphic gap which corresponds to Paleocene.

In order to verify if the same situation exists in Feredeu Digitation too (equivalent with Benia Digitation named by Săndulescu et al., 1993) we analysed the calcareous nannoplankton contained in deposits beginning from the lowermost part up to Demăcuşa level of this formation.

As in the case of Prisaca Digitation the sandstones cover the Variegated Formation. We also recognise the Demăcuşa mark bed, which crops out on the right side of Benia River, near the confluence with Tomnatec River. This is formed by coarse sandstones, rich in micas flakes (mainly muscovite), with large lithoclasts from Audia Formation as well as claystone clasts (possibly from Variegated Formation) (8 - $10 \mathrm{~m}$ or more). They are covered by microconglomerate unit $(0,8 \mathrm{~m})$ with feldspar (including orthose), quartz, and some lithic fragment (from Audia Formation) grains. The rhythmic flysch doesn't appear. Sandstones with lithic clasts probably substitute it. The sandstone with lithic clasts and microconglomeratic units are placed at $300 \mathrm{~m}$ above the boundary with Variegated Formation. Between the Variegated Formation and the units mentioned above there are massive sandstones $(300 \mathrm{~m})$. The upper part of Demăcuşa mark bed does not crop out being in tectonic relationships with Audia Formation.

The sandstones with lithic clasts also crop out on Sulita River. The best exposure is on Feredeu River and on Benia River downstream of the confluence with Feredeu River.

The lowermost part of Tomnatec Formation and the boundary with Variegated Formation crop out on Feredeu River. There is an unexposed part $(5 \mathrm{~m})$ between 
variegated claystones and Tomnatec Sandstone after which there crops out grey claystone $(3 \mathrm{~m})$. In these claystones (the sample no 9418 ) there were determined taxa, as follows: Fasciculithus tympanoformis (which marks the bottom of $\mathrm{NP}_{5}$ biozone and disappear in $\mathrm{NP}_{9}$ biozone), Fasciculithus lillianae and Fasciculithus aubertae (common in $\mathrm{NP}_{9}$ biozone), Fasciculithus clinatus $\left(\mathrm{NP}_{7}-\mathrm{NP}_{9}\right)$, Braarudosphaera bigelowi (mainly common in $\mathrm{NP}_{2}-\mathrm{NP}_{21}$ ), Chiasmolithus consuetus $\left(\mathrm{NP}_{5}-\mathrm{NP}_{9}\right.$ ), Heliolithus kneipellii $\left(\mathrm{NP}_{6}-\mathrm{NP}_{9}\right)$, Cruciplacolithus tenuis $\left(\mathrm{NP}_{2}-\mathrm{NP}_{9}\right)$, Ellipsolithus macellus $\left(\mathrm{NP}_{4}-\mathrm{NP}_{12}\right)$ and Marcalius inversus (Cretaceous - $\left.\mathrm{NP}_{23}\right)$. There are also some taxa reworked from Upper Cretaceous. The biostratigraphic value of these taxa (offered in the brackets after each bioform according to monography of Perch Nielsen, 1965) proves that the deposits belong to $\mathrm{NP}_{9}$ biozone (possibly its lower part) Uppermost Thanetian in age. The same situation was reported for Prisaca Digitation on lonul River.

The two others analyzed samples $(9412,9414)$ were took from claystone interbeddings among sandstone beds at the 80 stratigraphic thickness above the already described sample. The taxa assemblage of the two samples is formed by Discoaster deflandrey $\left(\mathrm{NP}_{10}-\mathrm{NP}_{25}\right)$, Discoaster multiradiatus $\left(\mathrm{NP}_{9}-\mathrm{NP}_{11}\right)$, Discoaster mohleri (upper part of $\mathrm{NP}_{7}-\mathrm{NP}_{9}$ biozone), Ellipsolithus macellus $\left(\mathrm{NP}_{4}-\mathrm{NP}_{12}\right)$, Braarudoshaera bigelowi $\left(\mathrm{NP}_{2}-\mathrm{NP}_{21}\right)$, Fasciculithus tympaniformis $\left(\mathrm{NP}_{5}-\mathrm{NP}_{9}\right)$, Rhabdosphaera pinguis, Rhabdosphaera scabrosa and Helicosphaera semilunum (Lower and Middle Eocene). According to the evolution span of the determined taxa (the extinction of some of them in $\mathrm{NP}_{9}$ and the apparition of Discoaster multiradiatus in $\mathrm{NP}_{9}$ ) we think that the nannoplankton assemblage belongs to upper or even uppermost part of $\mathrm{NP}_{9}$ biozone (Lower Ypresian). The $\mathrm{NP}_{9}$ biozone has a large age span between Upper Thanetian and Lower Ypresian.

The next claystone unit $(1 \mathrm{~m})$, at $35-40 \mathrm{~m}$ stratigraphic thicknesses from the above ones, was also analyzed. The sample 9428 contains taxa as follows: Discoaster martinii $\left(\mathrm{NP}_{15}-\mathrm{NP}_{16}\right)$, Discoaster saipanensis $\left(\mathrm{NP}_{15}-\mathrm{NP}_{20}\right)$, Rhabdosphaera inflata (upper part of $\mathrm{NP}_{14}$ - lower part of $\left.\mathrm{NP}_{15}\right)$, Rhabdosphaera crebra $\left(\mathrm{NP}_{15}-\mathrm{NP}_{19}\right)$, Rhabdosphaera pinguis (Lower and Middle Eocene), Lanternithus minutus ( $\mathrm{NP}_{15}$ $\left.\mathrm{NP}_{21}\right)$, Nannotherina cristata upper part of $\left.\mathrm{NP}_{14}-\mathrm{NP}_{15}\right)$, Chiasmolithus solitus $\left(\mathrm{NP}_{10}\right.$ $\mathrm{NP}_{16}$ ). The presence of some taxa with apparition or with extinction in $\mathrm{NP}_{15}$ (Lutetian) makes us to place the assemblage in this biozone. In the same sample there were also identified some taxa of Fasciculithus tympaniformis, Helicolithus kleinpelii, Cruciplacolithus tenuis which we consider to be reworked because they evolved only up to $\mathrm{NP}_{9}$ biozone.

After another $50 \mathrm{~m}$ stratigraphic thickness the 9432 sample was taken which contains Reticulosphaera umbilica $\left(\mathrm{NP}_{16}-\mathrm{NP}_{22}\right)$, Sphenolithus predistentus $\left(\mathrm{NP}_{14}\right.$ $\left.\mathrm{NP}_{25}\right)$, Discoaster deflandrei $\left(\mathrm{NP}_{10}-\mathrm{NP}_{25}\right)$, Zygrhablithus bijugatus $\left(\mathrm{NP}_{11}-\mathrm{NN}_{1}\right)$, Braarudosphaera bigelowi (Cenomanian - Lower Miocene), Rhabdosphaera scabrosa and Rhabdosphaera crebra (Lower and Middle Eocene), Helicosphaera compacta $\left(\mathrm{NP}_{17}-\mathrm{NP}_{24}\right)$. The later taxon determines us to place the above listed assemblage in $\mathrm{NP}_{17}$ biozone (Bartonian).

The last one sample was taken at $25 \mathrm{~m}$ beneath the Demăcuşa mark bed. The taxa assemblage contains Sphenolithus radians $\left(\mathrm{NP}_{11}-\mathrm{NP}_{19}\right)$, Sphenolithus predistenus $\left(\mathrm{NP}_{14}-\mathrm{NP}_{25}\right)$, Chiasmolithus consuetus $\left(\mathrm{NP}_{5}-\mathrm{NP}_{19}\right)$, Reticulofenestra umbilica $\left(\mathrm{NP}_{16}-\mathrm{NP}_{22}\right)$, Zygrhablithus bijugatus $\left(\mathrm{NP}_{11}-\mathrm{NN}_{1}\right)$. We think that this assemblage belongs to the upper part of $\mathrm{NP}_{18}$ biozone, which is Priabonian age. 
An argument for this interpretation would be the inferred age for the rhythmic flysch $(5 \mathrm{~m})$ of Demăcuşa mark bed which belongs to lower part of $\mathrm{NP}_{19}$ biozone (lonesi et al., 1998; Turturean, 1999).

\section{Conclusions}

The massive sandstones of Feredeu Digitation (named by Săndulescu et al., 1993 as Benia Sandstone) are equivalent to those of Prisaca Sandstone, which means they had to be named in the same way, that means Tomnatec Sandstone (Athanasiu, 1913) or Tomnatec Formation, on the priority rule basis. We argue this with the following arguments:

1. In both of the digitations, the Tomnatec Formation covers the Variegated Formation. Although between the Tomnatec and Variegated formations there seems to be conformable relationships, on nannoplankton stratigraphic value basis we proved that there is a gap corresponding with $\mathrm{NP}_{1}-\mathrm{NP}_{9}$ biozones (Paleocene but not Thanetian).

2. In both digitations we recognized the Demăcuşa mark bed in Tomnatec Formation.

3. Biostratigraphically, on nannoplankton data basis, the Tomnatec Formation belongs to $\mathrm{NP}_{9}-\mathrm{NP}_{20}$ biozones (Uppermost Thanetian or Lowermost Ypresian, Lutetian, Bartonian and Priabonian). The Bartonian deposits were dated also on large foraminifera basis (Senator mark unit).

\section{REFERENCES}

Agheorghiesei V., Cristodulo D., Marinescu I. (1965), Câteva observații geologice asupra flişului de Audia (Cernahora) din Bucovina, D. S. Com. Geol., LI/1, Bucureşti

Athanasiu S. (1913), Cercetări geologice în bazinul Moldovei din Bucovina, Raport asupra activității Inst. Geol. Rom. pe anii 1908 - 1909, Bucureşti

Aubry M. P. (1983), Corrélations biostratigraphiques entre les formations paléogène épicontinentales de l'Europa du Nord - Ouest basées sur la nannoplancton calcaire, Thèse Univ. P. et M. Curie, Paris 6

Băncilă I. (1952), Geologia regiunii Gura Humorului - Voroneț - Suha (Câmpulung şi Baia), D. S. Com. Geol., XXXVI, Bucureşti

Băncilă I. (1958), Geologia Carpaților Orientali, Ed. Ştiințifică, Bucureşti

Băncilă I., Agheorghiesei V. (1964), Observații asupra flişului dintre Valea Suha Mare şi Valea Moldovei, An. Com. Geol. XXXIII, Bucureşti

Ion Jana (1975), Vraconien - Turonien de la Nappe d'Audia (Bucovina), Micropal. Guide, $14^{\text {th }}$ Europ. Micropal. Coll. România, Bucureşti

lonesi L. (1965), Flişul paleogen dintre pârâul Valea Boului şi pârâul Valea Seacă, An. Şt. Univ. "Al. I. Cuza" laşi, sll -b, XI, laşi 


\section{LIVIU IONESI, FLORIN FLOREA}

Ionesi L. (1971), Flişul paleogen din bazinul Văii Moldova, Ed. Academiei, Bucureşti

lonesi L. (1974), Contributions à la connaisance de l'âge du grès de Prisaca (Carpathes Orientales), Bull. VI-e Congr. A. G. Carp.- Balk., I, Strat., 3, Warszawa

Ionesi L., Săndulescu Jana, Cârstov Eugenia (1967), Date microfaunistice asupra gresiei de Prisaca - Tomnatec, An. Şt. Univ. "Al. I. Cuza" laşi, sll -a (Geol. - Geogr.), XIII, Iaşi

Ionesi L., Meszaros N., Turturean M. (1998), Date noi asupra vârstei Formațiunii de Tomnatec - Prisaca (Pânza de Audia, Flişul Carpaților Orientali), Acad. Rom. Stud. Cerc. Geol., 42, Bucureşti

Macovei Gh. (1927), Aperçu géologique sur les Carpathes Orientales, Assoc. Géol. Carp., II - ème réunion, Guide, Bucureşti

Martini E. (1970), Standard Paleogene calcareous nannoplankton zonation, Nature, 226

Neagu Th. (1962), Studiul foraminiferelor aglutinante din argilele cretacic superioare de pe valea Sadovei (Câmpulung Moldovenesc) şi bazinul superior al văii Buzăului, Acad. Rom. Stud. Cerc. Geol., 7/1, Bucureşti

Paul K. (1876), Grundzüge der Geologie der Bukowina, Jb. K. k. geol. RA, XXVI, Viena

Perch - Nielsen Katarina (1985), Cenozoic carcareous nannofossils, Plank. Stratigr., Cambridge Univ. Press.

Săndulescu M. (1984), Geotectonica României, Ed. Tehnică, Bucureşti

Săndulescu M, Micu M., Alexandrescu Gr., Constantin P. (1987), Inst. Geol. Geofiz, Harta geologică a României sc. 1:50 000, Foaia 22b, Câmpulung Moldovenesc, Bucureşti

Săndulescu M., Antonescu E., Bratu Elena (1990), Contributions à la connaissance de l'âge du grés de Prisaca (Nappe d'Audia - Carpathes Orientales), D. S. Inst. Geol. Geof., 74/4, Bucureşti

Săndulescu M., Antonescu E., Neagu Th., Platon E. (1993), Grés de Benia position tectonique, âge et considèrations palèogéographiques (Carpathes Orientales), Rom. J. Tect. Reg. Geol., 75, Bucureşti 